\title{
WHERE HAVE ALL THE CONVERTS GONE? DIFFICULTIES IN THE STUDY OF CONVERSION TO ISLAM IN AL-ANDALUS
}

\author{
¿A DÓNDE FUERON LOS CONVERSOS AL \\ ISLAM? DIFICULTADES EN EL ESTUDIO DE LA \\ CONVERSIÓN AL ISLAM EN AL-ANDALUS
}

\author{
DAVID J. WASSERSTEIN * \\ Vanderbilt University, USA
}

\begin{abstract}
Discussion of a proposal for identifying converts to Islam in al-Andalus through their onomastics using the huge databases constituted by the medieval Arabic biographical dictionaries. The proposal is shown to be unworkable in practice. It is suggested in consequence that it may not be possible to identify converts in ways that are susceptible of statistical analysis.
\end{abstract}

Key words: Islam; Conversion; Al-Andalus; Onomastics; Names.
Este trabajo discute una reciente propuesta para identificar a conversos al Islam en alAndalus basada en su onomástica tal y como ésta se conserva en los diccionarios biográficos árabes del medievo. Se propone demostrar que esta propuesta no es viable en la práctica y, como consecuencia de ello, que no se puede identificar a tales conversos de forma que puedan someterse a un análisis estadístico.

Palabras clave: Islam; conversión; al-Andalus; onomástica; nombres.

The most exciting advance in the study of conversion to Islam produced in the modern period is undoubtedly Richard W. Bulliet's Conversion to Islam in the Medieval Period: An Essay in Quantitative History. In this work Bulliet chose to ignore virtually all previous scholarship on the subject, based as it was essentially in anecdotal accounts of individual conversions and general remarks about overall change in the religious character and identity of societies. Like the Prophet, Bulliet recognised that we cannot know what goes on inside

* I am grateful to the anonymous readers for Al-Qantara for helpful comments on the first draft of this article. 
a man's heart, and therefore cannot know why people in the middle ages changed their religious affiliations. But he thought that it might be possible to answer other questions, which concern not the individual but the mass in society: specifically, how fast did those populations, or those groups within populations, who converted to Islam do so? Was the speed standard throughout, or did it change? Did it vary from place to place, or among different groups within overall populations? And he sought to do so by quantitative means. In doing so, he married old-fashioned sources -biographical dictionaries- with modern, social scientific techniques -essentially those of elementary statistics- in order to produce a theory of conversion to Islam in the medieval period that went far beyond the mere construction of rates of progress to explain also much else in the field of Islamic history. If its reach did not perhaps quite match its ambition, the introduction of a new way of using such sources showed orientalists the potential that their sources possessed to produce new knowledge. If its findings were not always accepted, and if certain elements, however carefully explained, nevertheless failed, and still fail, to be understood by many readers, much in its basic thesis nonetheless remains central to our understanding of how the conversion of the peoples (as distinct from individuals) from Spain to the borders of India progressed between the conquest and the end of the middle ages. ${ }^{1}$ And its plausibility and acceptability as an argument are no whit reduced by the fact that the book's principal thesis seems also to be highly commonsensical.

The book suffers, though, from certain difficulties. One of the main difficulties with its argument was always the size of Bulliet's sample. It is small. It is taken from a fairly large overall data base, and as a result, especially for places which are very poorly represented in the sample, it has always seemed that the applicability of the thesis should be seen as even less persuasive for these places than

\footnotetext{
${ }^{1}$ For many readers and users of the book, it seems to have been impossible to understand that the entire thesis applies only to those people within a population who converted to Islam, and not to the population as a whole. Thus percentages refer generally to percentages of the islamised/islamising section of the population, not to percentages of the population as a whole. In the case of a country like al-Andalus, where we not only know nothing of the total population size at any time during the middle ages, but also know nothing of the size of that section of the population which remained Christian (to say nothing of the indeterminate size of the Jewish population at all periods), the point is not without significance. The same point could be made in respect of any of the territories of the early conquests outside the Arabian peninsula.
} 
for others. Those scholars who adopt such a position perhaps exaggerate a little, in ignoring the extent to which the applicability of the thesis to any particular area, say, al-Andalus, may gain support from the similarity of the results which the book offers here to those obtained for other areas. That similarity in itself, it may be suggested, constitutes additional support for the overall plausibility of the thesis. If it does not confirm the truth of the thesis put forward by Bulliet, the overall similarity of his results for all the areas which he studies must make it gain greater favour than results, however attractive, in one area alone could do.

Nonetheless, such overall similarity is founded in the end on the correctness and, especially, the thickness of detail, and it has frequently been pointed out that, for al-Andalus in particular, the sample available is very small. Some years ago, Mayte Penelas discussed the issue. In an article deriving from a presentation at the European Science Foundation's Workshop on 'Conversion to Islam in the Mediterranean', held in Rome in 1997, she drew attention once again to the problems of Bulliet's thesis in respect of al-Andalus and tried to suggest possible new directions in which we can find some compensation for the recognized lack of sampling thickness. ${ }^{2}$ She outlined the principal method used by Bulliet, and considered the degree of success in its application, and she went on to propose a possible addition to the corpus of approaches which quantitative analysis of the question of conversion to Islam in al-Andalus might adopt.

Penelas pointed especially to the major weakness of Bulliet's structure: it makes use only of a total of 154 genealogies for al-Andalus. These come from a data base of five biographical dictionaries covering the period from the second/eighth century to the first half of the seventh/thirteenth century (they are conveniently listed in her n. 8, and in Bulliet's own p. 152, n. 1), and including biographies of some 7,000 individuals. As she hinted, this number, representing less than 2.2 percent of the overall corpus from al-Andalus, compares poorly with the 469 genealogies which Bulliet used in his study of Iran, where they came from an overall corpus of "almost six thousand" biographies (Penelas, p. 194), so that in the Iranian case the percentage is closer to 7.8 percent, three and a half times greater. In addition to this fact, the Iranian corpus goes only up to 525/1130, and

\footnotetext{
2 Penelas, "Some remarks on conversion".
} 
in part only up to 390/1000, a fact which drives this point home more forcefully still. The coverage, both as to persons and as to chronology, in the Iranian case is simply very much denser.

This complex of facts, she argued, must make us worry about the reliability of Bulliet's findings: "he uses too few cases [to permit us] to consider the results as being completely valid, thus making it difficult to accept unreservedly the book's final conclusions" (Penelas, p. 193).

Penelas went on to enter a plea for new quantitative studies, and to offer one possible avenue for investigation. In doing so, she pointed out that "some information provided by biographical dictionaries or other kinds of sources -such as historical chronicles or juridical sources-, although [it] does not invalidate Bulliet's method, does suggest that there should be some reservation in accepting the results he obtains" (p. 193). Her formulation is very properly cautious, but I wonder whether, even thus expressed, it does not overstate the possible argument against Bulliet. As to the material to which she referred (though without giving any references), it can be urged that it is all of the anecdotal type - not in any derogatory sense of that word, but in the sense that it deals essentially with individuals and, even when these individuals are treated in context, their cases still do not offer us enough information to be useful for quantitative analysis, still less for the development of models for the quantitative analysis of a dynamic process extending over some four or five centuries and more.

In fact it is difficult to see how new models for such study can be developed in the absence of material, like that in the biographical dictionaries, susceptible of statistical treatment. Penelas' own example of one possible avenue illustrates this difficulty well. It involves two conditions: "The convert's father was named 'Abd Allāh"; and "The convert received the nisba al-Islāmî". Penelas does not make it clear whether she thinks that these two conditions both need to be fulfilled in each case, or whether each might on its own be a sufficient condition. As will be seen, in practice the question turns out not to be of great significance.

On a theoretical level, and based, as this is, on material derived from the fifth/eleventh-century work of Ibn al-'Attār about how conversions were to be recorded and preserved in documentary form, this looks at first sight like a useful possible line of approach. Unfortu- 
nately, as Penelas recognized (p. 199), there is just one solitary case in the biographical dictionaries at which she has looked of a convert who bears the nisba al-Islāmī. Alas for models, this al-Islāmī was not called 'Abd Allāh, but Ja'far, and in addition, as I have argued elsewhere, he is in all likelihood a fiction. ${ }^{3}$ This might not matter, in the sense that such a fiction is likely to have been fashioned according to well-known existing rules and norms, but fiction he is, and unique too. We have thus no one called 'Abd Allāh al-Islāmī, and no one even called al-Islāmī tout court. What of 'Abd Allāh?

Here matters are somewhat more complex. As Penelas pointed out, one of the problems of biographical dictionaries is that we cannot always be sure how complete their genealogical lists are. Occasionally, as she shows, we are now in a position, thanks to the devoted and selfless work of some of our Spanish colleagues, to identify flaws and, especially, gaps in such genealogies and to fill them out by cross-reference between different sources. Not everyone, to bring this point home to our present question, named 'Abd Allāh at the chronological head of a genealogical tree in our sources need by that token be seen as a convert's father. It may simply be that our tree is incomplete. So much is clear. This means, however, that both the criteria suggested by Penelas -Abd Allāh as a convert's father's name, and the nisba al-Islāmī- are either of no or of uncertain use in extending the range of possible converts for inclusion in the bank of individuals for quantitative analysis.

'Abd Allāh may, in fact, be of use for identifying possible converts in other ways and for other purposes. Each case, however, it seems to me, needs to be considered individually and in its context. It is worth showing why this is so. In the first place, numbers are so small that these cases cannot help the process of quantitative analysis; they are more likely to distort the picture than to clarify it. And the context of each case, considered individually, is likely to illustrate this fact as it is also likely to show which cases really may be those of conversions and which are probably not. Two kinds of example will illustrate this point.

The first is the case of Ghirbib b. 'Abd Allāh. Ghirbib lived in the first century or so after the conquest, and was active in Toledo, possibly with a Cordoban connection; he wrote Arabic poetry in sup-

3 Wasserstein, "Inventing Tradition". 
port of Toledan rebels against the Umayyads of Cordoba. He has only a single named ancestor in our sources, 'Abd Allāh. Ever since Dozy, some scholars have thought to see in him a descendant of local Christians, rapidly islamised and arabised, and hostile, like so many others in Toledo, to outside rule. I have argued elsewhere, however, that this characterization of Ghirbib is mistaken: Dozy (and those who have followed him) simply erred in understanding the sources. Ghirbib was in fact an Arab; we have no reason to imagine him as anything else and we have every reason to see him as a member of the class in which he was active, that of the conquerors of Christian Spain, not as a convert from Christianity to Islam. ${ }^{4}$

The other case is more complex. Penelas refers to it as the naming of the convert's father as 'Abd Allāh. This is just a little astray. The source upon which she relies here, the formulary of Ibn al'Attār, produced in the fifth/eleventh century, contains sample documents showing how conversions were to be recorded. In the place where the convert's name was to be inserted, it tells us, one should insert "so-and-so son of so-and-so", "unless the father's name is one of the awkard names of the non-Arabs". ${ }^{5}$ In such a case one should record it as "Abd Allāh, "for we are all servants of God", and "Abd Allāh means, literally, servant of God. This is a replacing of the man's father's name, not, quite, a re-naming of a man's father, though it may seem to come close. However, it is reasonable to assume that it might survive in biographies as the earliest name in a person's genealogy. It is therefore worth looking at our material to see how far it may offer examples of converts. The results are not very encouraging.

For this purpose I had recourse to the excellent and extremely useful list compiled by Manuela Marín, some twenty years ago, of names of learned men in al-Andalus between the conquest and the end of the reign of 'Abd al-Rahmān III al-Nāṣir, covering, that is to say, a period of two hundred and fifty years, from $92-3 / 711$ to

\footnotetext{
4 Wasserstein, "Ghirbib ibn 'Abd Allāh al-Thaqafî”.

5 Ibn al-'Attār, Formulario notarial hispano-árabe, p. 406: wa-in lam yu 'raflya 'rif ism abïhi aw kāna min asmā' al- 'ajam al-thaqïla al-karīha qulta... ("And if his father's name is not known or if it is one of the foreign names that are heavy and ugly, then you say..."). See, for discussion of the document as a whole, Chalmeta, "Le passage à l'Islam dans al-Andalus" and Abumalham, "La conversión según formularios notariales andalusíes".
} 
350/961. ${ }^{6}$ Based on a variety of biographical dictionaries, it has the merit, besides that of saving the scholar's time, of combining the material, eliminating repetition, and collecting together in one place, and in uniform manner, a good deal of information that makes it possible to conduct just this sort of enquiry with ease. (The corpus thus prepared is smaller than that of Bulliet, and covers a shorter chronological stretch, but this is not a statistical survey, and the narrower scope is of no harm in this case. Later material, such as that in the biographical dictionaries for the fifth/eleventh century and after, is deliberately excluded here for another reason: by the fifth/eleventh century naming habits, conversion patterns and the composition of the population had all changed, and the relative stability that characterizes al-Andalus in the earlier period was gone, making comparison much more difficult.) Her list contains some 1631 entries (there may be some very slight repetition, but this is not statistically significant; nor are statistics, as such, of any relevance to my argument here). Among these, I extracted all those which contain the name 'Abd Allāh in the chronologically earliest position; there were a total of 40 , some 2.5 percent of the total.

Here are the individuals concerned. The initial numbering is my own; the second number in each case is that in Marín's list. As Marín gives a full set of bibliographical references for the sources for the biography of each individual, there is no need to repeat the exercise here (d. = died; I take the dates from Marín where she gives them).

1. 20: Ibrāhīm b. Ḥamdān b. 'Abd Allāh; Abū Isḥāq, d. 318/930.

2. 68: Abū Sa'd b. 'Abd Allāh al-Haḍramī; of Saragossa.

3. 138: Ahmad b. 'Abd Allāh; of Cordoba, d. after 286/899.

4. 139: Aḥmad b. 'Abd Allāh; Ibn Ghumāmā, of Rayyo.

5. 140: Aḥmad b. 'Abd Allāh; al-Anșārī, of Rayyo and Elvira, d. after $238 / 856$.

6. 141: Aḥmad b. 'Abd Allāh; al-Qaynī, of Rayyo, d. c. 326/ 937-38.

7. 263: Aswār b. 'Uqba b. Hassān b. 'Abd Allāh; Abū 'Uqba, al-Nașrī, of Jaén and Cordoba, d. 213/828.

8. 288: Umayya b. 'Abd Allāh; of Ecija, d. 296/908-09.

9. 322: Bakr b. 'Abd Allāh; Ibn al-Qamāla, al-Kilā'‘̄i, d. after $234 / 848$. He is presumably the father of no. 29 , q.v.

"Marín, "Nomina de sabios de al-Andalus". 
10. 414: Hafṣ b. 'Abd Allāh; al-Anșārī, of Saragossa, d. after $311 / 923$.

11. 455: Khalaf b. 'Abd Allāh; Khalf al-Hurma, of Cordoba, d. after $286 / 899$.

12. 465: Da'ud b. 'Abd Allāh; al-Qaysī, of Seville, d. c. $271 / 883$.

13. 505: Ziyād b. 'Abd Allāh; al-Ansārī, of Toledo, d. 212/827.

14. 551: Sa'īd b. 'Abd Allāh ('Abd al-Raḥmān); Abū 'Āmir, al-Sibā'̄ d. d. after 138/756.

15. 555: Sa'īd b. 'Uthmān b. Sulaymān b. Sa'īd b. Sulaymān b. Muhammad b. Malik b. 'Abd Allāh; Tujībī, d. 305/917.

16. 569 (probably repeated at 571): Sa'īd b. Marwān (b. 'Affān b. Muzayn) b. Mālik b. 'Abd Allāh; Abū 'Uthmān, alHadramī, of Tudela, d. 335/946.

[16a. 571: Sa'īid b. Maqrūn b. 'Affān b. Maqrūn b. Mālik b. 'Abd Allāh; al-Yahṣubīi, al-Tuțîlī, of Tudela.]

17. 617: Shabtūn b. 'Abd Allāh; al-Anșārī, of Toledo, d. 212/827 or $222 / 836-37$.

18. 648: Țāhir b. 'Abd al-'Azīz b. 'Abd Allāh; Abū al-Hasān, al-Ru'aynī, of Cordoba, d. 304/916 or 305/917.

19. 704: 'Abd al-Raḥmān b. 'Abd Allāh; al-Ghāfiqī, al-'Akkī, d. $114 / 732$ or $115 / 733$.

20. 716: 'Abd al-Rahmān b. Maslama b. Sa‘īd b. Tibri b. Ismā'īl b. Sulaymān b. Muntaqim b. Sulaymān b. Ismā'īl b. 'Abd Allāh; Abū al-Muțarrif, of Carmona and Cordoba, d. 338/949.

21. 735: 'Abd al-'Azīz b. 'Abd Allāh; al-Sulamī.

22. 919: 'Arrām b. 'Abd Allāh; al-Bāhilī, al-'Āmil̄̄ (are these doublets?), d. 256/869-70.

23. 923: 'Ufayr b. Mas'ūd b. 'Ufayr b. Bishr b. Faḍala b. 'Abd Allāh; Abū al-Hazm, al-Ghassānī, of Moron, Seville and Cordoba, d. 317/929.

24. 997: 'Īsā b. 'Abd Allāh; al-Ṭawīl, of al-Madīna al-Munawwara (i.e., Madīna), d. after 93/711.

25. 1018: Ghirbib b. 'Abd Allāh; Abū 'Abd Allāh al-Thaqafì al-Tulaytuli , of Toledo, d. 207/822 (This is the Ghirbib mentioned above).

26. 1032: Faraj b. 'Abd Allāh; al-Khurāsān̄̄, of Toledo, d. 295/907-08. 
27. 1037: Farqad b. 'Abd Allāh; al-Jarashi, of Saragossa and Cordoba, d. after 172/788.

28. 1085: Lubb b. 'Abd Allāh; Abū Muhammad, of Saragossa, d. c. $300 / 912$.

29. 1155: Muhammad b. Bakr b. 'Abd Allāh; Abū al-Qāsim, al-'Amāla (al-Qamāla) Ibn al-Mu'addib al-Kilā‘'̄, of Cordoba, d. $305 / 917,307 / 919$ or $308 / 920$. He is presumably the son of no. 9, q.v.

30. 1229: Muhammad b. 'Abd Allāh; Abū Bakr al-Ru'aynī, of Rayyo, d. after 286/899.

31. 1230: Muhammad b. 'Abd Allāh; Abū 'Abd Allāh Ibn alAsfār al-Makfuf al-Qurashī, of Seville and Cordoba, d. after 300/912.

32. 1231: Muhammad b. 'Abd Allāh; Ibn al-Quq al-Khawlān̄̄ al-Bājī al-Ishbīlì, of Cordoba, d. 307/919.

33. 1232: Muhammad b. 'Abd Allāh; Abū 'Abd Allāh, of Khurāsān, d. 282/895 (?).

34. 1233: Muḥammad b. 'Abd Allāh; Abū 'Abd Allāh, of Cordoba, d. after 180/796.

35. 1234: Muḥammad ('Abd Allāh) b. 'Abd Allāh; al-Bazzāz, al-Matmatī, d. after 179/795.

36. 1235: Muhammad b. 'Abd Allāh; al-Fihrī, of Tudela.

37. 1236: Muhammad b. 'Abd Allāh; al-Laythī, d. 347/958.

38. 1464: Nașr b. 'Abd Allāh; Abū al-Shimr, al-Aslāmī, of Tudmir, d. after 313/915 (sic; this is presumably a misprint for 925-26).

39. 1490: Humām b. 'Abd Allāh; al-Andalusī, d. after 179/795.

40. 1558: Yahyyā b. 'Abd Allāh; Ibn Ghaland, of Saragossa, d. after 286/899 (It is not clear to me that we should not see Ghaland as a Christian personal name).

These forty names come from a total, it is worth recalling, of ca. 1630 , and thus represent some 2.5 percent of our total. Bulliet's Andalusi sample represented only 2.2 percent of his overall Andalusi corpus, while in the Iranian case he was able to look at a sample two and a half times bigger. This percentage is virtually the same as his and must cause a little worry already at the start. We note at once that out of these forty, only eight (nos. 1, 7, 15, 16, 18, 20, 23, and 29) can name their grandfathers (or go beyond him to list further ancestors). Of these 
eight, three can name their grandfather but cannot go further back. One can name three generations of ancestors; two can name five; one can name seven, and another can name a scarcely believable 9 generations. If we look at things from the other end, out of these forty, fully thirty two, or four fifths, know the names of only a single ancestor. And in all of these 32 cases, as in the cases of the most remote named ancestor of the other eight as well, that single ancestor is called 'Abd Allāh.?

At first sight, the fact that we have such a comfortably large number of individuals, and the fact that such a large proportion, eighty percent, of them have (or at least know) only one named ancestor in Islam, might seem to offer support to the idea mentioned earlier: 'Abd Allāh as the name of a father (or ancestor), in combination with the absence of any named Muslim chronologically earlier in the family tree, indicates a conversion, in the time of the son of that (alleged) 'Abd Allāh. ${ }^{8}$ This list offers no such easy comfort. Closer analysis of its contents shows why.

We may conveniently begin with those individuals with long ancestries. No. 20, with nine ancestors named, died in 338/949. If we apply to his ancestry the estimate worked out by Bulliet for average generation length (i.e., the time between a man's birth and the birth of his son), something of the order of thirty four years, we find ourselves way back beyond the Muslim invasion of Spain and around the birth of Islam itself. ' Abd Allāh, in this case, if it is an authentic record of a genuine ancestry, even if he was actually a convert to Islam, is not relevant for us, as he was almost certainly an Arab in the Arabian peninsula. No. 15, with seven named ancestors, has the nisba al-Tujībi $\overline{1}$, and is therefore probably an Arab by descent too. ${ }^{10}$

${ }^{7}$ We should not ignore the possibility of invention here, but if someone were going to invent an Arab background for himself, we might expect him to invent more than a couple of generations of ancestry too.

${ }^{8}$ Of course Ghirbib b. 'Abd Allāh (no. 25) offers the proof that this is never necessarily so.

9 There may be grounds for believing that Bulliet's estimate is, in the Andalusi case, considerably shorter than it should be. If that is so, then of course that would strengthen the point being made here.

${ }^{10}$ I stress here the word 'probably', for we cannot ignore the possibility of forgery of ancestries by those interested in allying themselves with the rulers by pseudo-genealogical means. But at a time when numbers of Muslims with Arab ancestries in al-Andalus were still relatively small, and registries of them were being maintained, it seems reasonable to suppose that invention of this kind will have been limited. 
No. 16, with five named ancestors, is described as al-Hadramī (in the case of no. 16a, of which it is probably a doublet, as al-Yahṣubī), and is therefore also to be similarly discarded from consideration here. No. 23, also with five named ancestors, is called al-Ghassānī, and can be removed from consideration here for the same reason. No. 7, called al-Nașrī, with three named ancestors, also has such unusual names (Aswār b. 'Uqba b. Hassān b. 'Abd Allāh) that it is probably safe to see him as an Arab too. There remain, in this small sub-group, the three individuals who can name their ancestors only as far back as their grandfather: nos. 1, 18 and 29. Of these, no. 18 is called alRu'ayni and no. 29 is called al-Kilā' $\overline{1}$ (he must be the son of no. 9); both can therefore be disregarded here. Only no. 1 lacks such an identificatory label, but his father's name is Hamdān, again a highly unusual name for us to find in a convert.

If we turn to the rest, then the picture is not very different. These thirty two genealogies each give only one generation backwards, that of the father. In all cases, the name is, of course, 'Abd Allāh. Of these 32 , fully 24 have a nisba or other label which makes it clear that we have not to do here with an invented paternal name: ${ }^{11}$ no. 2 is a Hadramī; nos. 5, 10, 13, 17 are Ansaris; ${ }^{12}$ no. 6 is al-Qaynī; no. 9 is Kilā' ' 1 (he must be the father of no. 29); no. 12 is Qaysī; no. 14 is Sibā' $\mathbf{1}$ (in this case there is also some doubt about the father's name: it may have been 'Abd al-Raḥmān); no. 19 is Ghāfiqī; no. 21 is Sulamī; no. 22 Bāhilī (or 'Āmilī); no. 24 comes, we are told, from Madīna; no. 25 is a Thaqāfĩ (this is the Ghirbib mentioned earlier); no. 26 is described as Khurāsānī, so presumably any conversion took place among the population of that territory and is not relevant here; no. 27 is described as Jarashî, presumably with a background in Jerash, in present-day Jordan; no. 30 is a Ru'aynī; no. 31 is a Qurashī; no. 32 is ascribed to the tribe of Khawlān; no. 33 seems also to come from Khurāsān; no. 35, Matmatī, seems to be a Berber, once again

${ }^{11}$ I exclude here the possibility of walā': a convert or his son might bear such a nisba via wala'. This possibility certainly exists, but while we have no way at all of checking this, we might expect some indication of it to come through our sources. As can be seen, it affects only a small proportion of these names.

${ }_{12}$ As Maribel Fierro ("La nisba al-Ansārî", esp. p. 233) points out, this nisba becomes very common in al-Andalus in the fifth/eleventh century. However, we are concerned here only with the period up to the middle of the fourth/tenth century, when it may still be regarded as a quasi-tribal name. 
an outsider to the peninsula; no. 36 is a Fihrī; no. 37 a Laythī; and no. 38 an Aslāmī (for the vital difference between aslāmī and islāmī, see Penelas, p. 199). So all of these can also be removed from consideration here as possible converts. (As I have said, I do not exclude the possibility of invention, or falsification, of ancestry - but the relatively small size of the Muslim population before the middle of the fourth/tenth century, and the apparent existence of registers listing people with their genealogies, may be regarded as at least a partial protection against the effects of this. To the extent that such invention does occur in this group, moreover, looking at the name 'Abd Allāh will not help us to find it, or to identify converts.)

There remain now only eight of our original forty. These are nos. $3,4,8,11,28,34,39$, and 40. Some of these could be converts: we might see nos. 3 (Aḥmad), 4 (Ahmad) and 34 (Muhammad) as converts who had adopted new names following their conversion and chosen to adopt very Islamic names for themselves, along with the name 'Abd Allāh for their fathers. In the same spirit, we might see no. 8 , born probably in the middle of the third/ninth century, as having chosen the name Umayya as being a name redolent of the Arab character of the rulers of al-Andalus at that time. This would account happily for half of our little group here. The second half would not be so easily explained: no. 11 is a Khalaf, simply an ordinary Arab name, with no specially Islamic character; no. 39 is Humām, which is such an extremely rare name in Arabic that we are almost bound to see this as the name of an Arab, rather than as that of a convert with an antiquarian leaning; no. 40, Yahyā, by contrast, could simply be a Christian name in Arabic dress (this man's grandfather, if Ibn Ghaland does reflect a real grandfather - and not some sort of nickname - and a real, Latin name, could easily have been a Christian - if so, he or his father 'Abd Allāh may be a solitary convert here ${ }^{13}$ ); and as for no. 28, the Saragossan Lubb (> Latin lupus) becomes a not too uncommon name among certain families in north-eastern al-Andalus, so that in this case it might just be an indication of a convert, though we might wonder whether it would be likely that we should find it

${ }^{13}$ Ghaland $=\mathrm{G}(\mathrm{h})$ alindo. For examples of this name see Simonet, Historia de los Mozárabes de España, p. 191, p. 281 and n. 1; p. 114, n. 2 and p. 421. What is really striking in this case is that all these fully Christian examples of the name come from more or less the same period as our example; and we (seem to) have none from an Islamic context from any other period. 
in the first generation of neo-Muslims. Once again, this little subgroup, like the other thirty two names in our overall sample, offers us little by way of conversion or of converts. At best, we might be able to see here four or five converts: nos. $3,4,34$, and possibly 8 , together with no. 40.

However, our ability to see even these (apart from no. 40) as converts depends crucially on two conditions, not identical to those set by Penelas. She, it will be recalled, laid down two conditions for the identification of converts: that the convert's father should be named 'Abd Allāh; and that he should bear the nisba al-Islāmī. We have no one called al-Islāmī; and as we have seen, of all those people before 350/961 whom we can find in Marín's list who have an earliest named ancestor called 'Abd Allāh, a total of forty, only four (other than no. 40), at the very best, might be seen as possible converts (for a percentage of the total corpus of 0.2 percent - scarcely significant in any statistical, or other, sense). But it seems to me that even for these to be converts we have to imagine two conditions different from those laid down by Penelas: the first is, as with Penelas, that his father's name should be re-formulated as 'Abd Allāh; the second, not with Penelas, is that he should himself have changed his own name upon conversion. Each of these calls for a little explanation.

As to the first, there is a slight problem here. As Penelas points out, our source for the notion of re-formulating a convert's father's name, Ibn al-'Attār, writing in the fifth/eleventh century, long after the time of all the individuals under study here, suggested doing this, but he suggested it, very explicitly, for cases where the father's real name was ugly and difficult to pronounce. ${ }^{14} \mathrm{He}$ did not suggest that this was a requirement or a recommendation in all cases. It would be a singularly happy coincidence of onomastic ugliness and bureaucratic convenience if all the converts of whom we have such a record did indeed have fathers with names that were ugly and hard for an Arab to pronounce, but coincidences are not as common as we should like. No. 40 Yahyyā b. 'Abd Allāh Ibn Ghaland might look like such a case, but he is not: the "ugly" name, the name that does not wear a suitably Arabic appearance, is the grandfather's, and it has not been changed. In any case, as Bulliet's study demonstrated, we have quite

${ }^{14}$ See above.

Al-Qanțara XXXIII 2, 2012, pp. 325-342 ISSN 0211-3589 doi:10.3989/alqantara.2011.005 
a supply of genuine names of people whom we cannot reasonably regard as anything but the fathers of real converts; and in virtually all of them we might very reasonably see names that are ugly and hard to pronounce.

The second condition is that the convert should have changed his name upon conversion. Penelas, depending here on Bulliet, suggests that change of name upon conversion was a norm, "probably the normal practice" (Penelas, p. 194, citing Bulliet, p. 19, with his n. 5 on p. 142). This seems a large assumption. Bulliet says (p. 142, n. 5) that "Most Iranian converts to Islam identified in chronicles and other sources bear Arabic names. Retention of a Persian name is the exception, but in ascertainable cases the Persian name is indeed borne by a Muslim and is not simply the name of the non-Muslim father of the first family member to have an Arabic name". This is not as clear as we might wish: the first clause of the second sentence seems not fully compatible with the rest of it. In any case, however this may be, the Iranian situation need not have been the same as that in alAndalus. We do not know enough to compare the two situations. Here, moreover, we do not have a supply of Andalusi "converts identified in chronicles and other sources" to help us in this way, and we have to go on other evidence, or the lack of it. In the Andalusi case, we do not have any indication at all, whether in chronicles or in other sources, to the effect that converts did change their names upon changing their faith. ${ }^{15}$ We simply do not know. But ignorance

15 There is one example of something superficially similar, in part: Maribel Fierro, in a discussion of "Árabes, beréberes, muladíes y mawāl $\vec{\imath}$ ”, p. 48, n. 37, draws attention to the case of someone called 'Abd Allāh b. 'Abd al-Wārith/'Abd al-Hārith b. Muntil/ Mantil (who died in Ramadan 373/February-March 984). According to the Qādī 'Iyāḍ, this man was really called Muntil/Mantil, like his grandfather (conforming to a pattern of naming that is extremely common), but he was called 'Abd Allāh by one of his teachers (because Mantil/Muntil was "ugly" or difficult to pronounce? Or because it was not Islamic enough? Or for some other, unknown reason?), with the name-change, it is to be understood, sticking, and providing, furthermore, the name under which he appears in the sources. Here, of course, there is no question of a conversion taking place as the background to a name-change. Nor is the change of name in the generation of any islamization. Nor, most significantly, is the name-change associated with a person's father, but with the person himself. Nonetheless, the fact of a name-change here is of interest, as is also the fact that the new name is "Abd Allāh. Fierro suggests that this seems to be an interesting case of the survival of a non-Islamic name into the second generation of Muslims. If Muntil/Mantil was in fact the man's original name, then what is interesting is the survival of such a non-Islamic name in the context of Islamic naming patterns across generations. We do have other examples of survival of non-Islamic/ 
of an action cannot be taken as evidence for it. And, perhaps still more to the point here, Bulliet's theory, as applied to al-Andalus as elsewhere, requires that the convert both keep his own name (in order for him to be findable in the biographical dictionaries) and give his son an Arab - or Muslim-sounding one. While we hear from Ibn al'Attār, a legal type, about re-formulating the name of a convert's father, surely not the most important element in anyone's name or identity, we hear nothing from him about any name-change for the convert himself. This is a loud silence in such a context. The plain fact is that we hear nothing about such a practice. And this means that we cannot simply imagine that an entire group of people, like our little sub-group of four potential converts identified above (nos. $3,4,34$ and possibly 8 in my list) are people who did this. It would require us to argue in the following way: these people may have converted to Islam, and the proof of that is that they changed their names; and the proof of that is that they have Islamic names, even though we have no knowledge of any other names that they may have had before, and are in no case informed about any such change, as we are also not informed about any such practice in al-Andalus or elsewhere west of Iran. Having an Islamic name thus becomes evidence of having previously had a non-Islamic one. Such a position cannot be reasonably sustained.

The two conditions laid down above for seeing our four candidates for converts as such cannot, therefore, be fulfilled: since they cannot, we have no good reason to classify them in this way. And this in its turn means that of our original group of forty potential converts, not one certain convert remains, and scarcely even a single potential one (no. 40 Yahyā b. 'Abd Allāh Ibn Ghaland - but even this depends on the assumption that Ghaland is a Christian personal name).

This means that 'Abd Allāh, as the name of a man's father, is not automatically to be seen as an indication of a convert. It may be that in certain cases, but only when the individual case has been subjected to careful scrutiny. Here is one such example, from a slightly later period. He does not appear in the list prepared by Marín, for whom he is too late, but he does occur in a list prepared by María

Arabic names into the second and even further generations of Islam: see Wasserstein, "Inventing Tradition", pp. 280-283. 
Luisa Ávila in 1985 which fills the same function as that of Marín, though for the century immediately following hers, 350/961-450/1058. Ávila's no. 344 is Aḥmad b. Sulaymān b. Ayyub b. Sulaymān b. Hakam b. 'Abd Allāh, and he died in early 388/January $998 .{ }^{16} \mathrm{He}$ is interesting here for several reasons: he can name his ancestors for five generations, back to his great-great-great-grandfather; the earliest of these is 'Abd Allāh; and we learn from our sources on him also that he could name two further generations, both of them very nonArab(ic) and non-Islamic: these were 'Abd Allāh's father, al-Balakayush, and his father, 'Ulyān, al-Qūṭ̂̀. Al-Qūtī (whatever truth there may be to this label [= "the Goth"] as applied to "Ulyān here) is a pointer to Ahmad's status as the descendant of a convert of local background. It means that the man who bore this name was definitely not an Arab and hence that a conversion had taken place somewhere among his descendants. But which of the people in this genealogy was the convert? Was it 'Abd Allāh? In that case, Penelas' argument about 'Abd Allāh being used to replace the awkwardsounding name of the father of a convert fails. Was it in that case 'Abd Allāh's son, Hakam? But then we should have here - in 'Abd Allāh and al-Balakayush and 'Ulyān - what seems to be the only case in our sources where we know the names of three generations of non-Islamic ancestors of a Muslim. ${ }^{17}$ Bulliet's thesis depends on the notion that our genealogies offer us only one generation of pre-Islamic ancestry. Was it in that case 'Abd Allāh's father, al-Balakayush? But then why is 'Ulyān mentioned? He must be Julian, the famous governor of Ceuta in 92/711. Is this why his name appears here? We cannot know on the basis of the genealogy. And without knowledge from other sources, in fact, we cannot know for sure which of these four men was the convert. Any of them could have been. What seems most likely is that 'Ulyān (if he ever existed), as the earliest person

16 Ávila, La Sociedad hispanomusulmana al final del califato, p. 119, no. 344, with references to Ibn al-Faradī and the Qādī 'Iyāḍ.

${ }^{17}$ For the argument on this see Wasserstein, "Inventing Tradition". It is worth reminding ourselves that Ibn al- 'Attar suggested replacing a father's name with "Abd Allāh purely for reasons of aesthetics: he speaks of names that are "ugly" or "awkward to pronounce" for Arabic-speakers. He is not trying to give such fathers an Islamic name, far less, in Mormon fashion, to convert them retrospectively. If 'Abd Allāh in this genealogy represents this sort of convenience, therefore, we are entitled to ask why such convenience was not extended also to his father and grandfather to make their names fit in more tidily to Arabic sound- and word-patterns. 
named here, was the convert, or, more importantly, was intended to be understood here as the convert. But, given Julian's significance in the narratives of the conquest, and the fictions that arose about that event, that cannot be regarded as knowledge or as certain.

Careful scrutiny in this case, where we have an 'Abd Allāh as the earliest Islamic/Arab name in a genealogy -but not as the earliest name in a genealogy- has not told us what we need to know: by itself, even in this position in a genealogy, the name 'Abd Allāh cannot tell us that we have a convert; without the nisba al-Qūtî, or one of the generational names al-Balakayush and 'Ulyān, we should not even have any way of knowing that a conversion occurred at all somewhere in this family. And even with these bits of information we still do not know, from the genealogy or without external aid, who the convert was. This in its turn means that, even if we actually did have numerous such cases in our sources, we could not use them for the construction of statistical models built on quantitative techniques.

This may not mean that we cannot refine the model proposed by Bulliet in its application to al-Andalus, but it does mean that we need to find more, and more reliable, material susceptible of quantitative analysis, or alternatively discover different methods for the quantitative analysis of the material that we have.

\section{Bibliography}

Abumalham, Montserrat, "La conversión según formularios notariales andalusíes: valoración de la legalidad de la conversión de Maimónides", Miscelánea de Estudios Árabes y Hebraicos, 34 (1985), pp. 71-84.

Ávila, María Luisa, La Sociedad hispanomusulmana al final del califato (Aproximación a un estudio demográfico), Madrid, CSIC, 1985.

Bulliet, Richard W., Conversion to Islam in the Medieval Period: An Essay in Quantitative History, Cambridge, Mass., Harvard University Press, 1979.

Chalmeta, Pedro, "Le passage à l'Islam dans al-Andalus au $\mathrm{X}^{\mathrm{e}}$ siècle", in Actas del XII Congreso de la U.E.A.I. (Málaga 1984), Madrid, Union Européenne d'Arabisants et d'Islamisants, 1986, pp. 161-183.

Fierro, Maribel, "Árabes, beréberes, muladíes y mawālī. Algunas reflexiones sobre los datos de los diccionarios biográficos andalusíes", en Marín, Manuela y Felipe, Helena de (ed.), Estudios onomástico-biográficos de alAndalus (EOBA), VII, Madrid, CSIC, 1995, pp. 41-54. 
Fierro, Maribel, "La nisba al-Anșārī en al-Andalus y el cadí Mundir b. Sa'īd", Al-Qantara, 25 (2004), pp. 233-237.

Ibn al-'Attār, Formulario notarial hispano-árabe, Kitab al-Wathā'iq wal-Sijillāt, Chalmeta, P. and Corriente, F. (ed.), Madrid, Academia Matritense del Notariado-Instituto Hispano-Arabe de Cultura, 1983.

Marín, Manuela, "Nómina de sabios de al-Andalus (93-350/711-961)", en Marín, Manuela (ed.), Estudios onomástico-biográficos de al-Andalus (EOBA), I, Madrid, CSIC, 1988, pp. 23-182.

Penelas, Mayte, "Some remarks on conversion to Islam in al-Andalus", $A l$ Qantara, 23 (2002), pp. 193-200.

Simonet, Francisco, Historia de los Mozárabes de España, Madrid, Real Academia de la Historia, 1897-1903.

Wasserstein, David J., "Ghirbīb ibn 'Abd Allāh al-Thaqafī and the beginnings of linguistic and ethnic accommodation to Arab Islam in al-Andalus", in Hoyland, Robert and Kennedy, Philip (ed.), Islamic Reflections Arabic Musings, Studies in Honour of Alan Jones, Oxford, Gibb Memorial Trust, 2004, pp. 217-29.

Wasserstein, David J., "Inventing Tradition and Constructing Identity: The Genealogy of 'Umar Ibn Hafṣūn Between Christianity and Islam”, AlQanțara, 23, 2 (2002), pp. 269-97.

Recibido: 18/10/2011

Aceptado: 14/03/2012 